\title{
Indicative planning in the Russian economy: a crisis-prevention instrument
}

\author{
Igor I. Smagin \\ Tambov State University named after G.R. Derzhavin, \\ Institute of Economics, Management and Service \\ Tambov, Russia \\ troveo@mail.ru
}

\author{
Victoria I. Smagina \\ Moscow State Transport University (MIIT) \\ Institute of Economics and Finance \\ Moscow, Russia \\ snvika@ rambler.ru
}

\author{
Nilolay V. Strekalov \\ Tambov State University named after G.R. Derzhavin, \\ PHD student of the Department of Political Economy and Modern Business Processes \\ Tambov, Russia \\ NVStrekalov@outlook.com
}

\begin{abstract}
In the current development of the Russian economy, crisis-prevention instruments are needed. Indicative planning could be a solution to this problem.
\end{abstract}

Keywords - Russian economy, indicative planning, crisisprevention instruments

\section{INTRODUCTION}

In the current development of the Russian economy, it is important and necessary to use crisis-prevention instruments that increase the level of the well-being of the population. It is necessary to develop the indicators of the effectiveness of this process. Indicative planning allows you to do the tasks assigned to the region and choose the most effective strategy.

It's crucial to expand the prospect of applying indicative planning for the Russian economy.

The research objectives: to reveal the advantages of indicative planning in the Russian economy; to study the limiting factors that prevent the effective use of this method, to offer options for implementing the long-term strategy of the region in the concept of indicative planning.

\section{MATERIALS AND MethodS (MODEL)}

We stand for indicative planning of effective tools for reforming the favorable social and economic environment in the region. Today there is no single conceptual approach to creating a stable development of the region.

The territory of the Russian Federation is large and diverse, and the economic level of the development of the regions for a number of indicators is significantly different. It is impossible to apply a single methodological basis. It is necessary to formulate tasks regarding the target state of a number of parameters of the social and economic system of the region, for example, the development of indicators for determining the effectiveness of the educational process.
Therefore, indicative planning is a framework that has the appropriate tools for developing individual and most effective development strategies for each region. Indicative planning is the tool that allows to get a positive result at the interface between meso- and macro levels (an example of this is the US project, the Tennessee River - united a number of regions).

The prospect of introducing indicative planning in the Russian Federation also has a number of advantages that other approaches to managing the national economy do not possess:

1. Creation of a general economic plan for effective interaction between the state and business.

2. In constructing a long-term strategy for the development of the region there is feedback for considering the changes in the foreign policy and foreign economic sphere resulted from deviations from the goals and objectives set in the long-term perspective.

3. Indicative planning reflects the activities of the state and the regions transparent, and allows evaluating these actions in order to achieve the targets.

Indicative planning allows forming an economic prototype of the functioning of the state in the long term; the use of indicative planning has real possibilities for their determination and in short planning intervals (1-3 years).

Considering the region as a subject having a certain independence in the formation of the concept of its own social and economic development, as well as the degree of autonomy in making a number of decisions, we should note that in most cases local leadership has sufficient qualifications for implementing measures to restore and develop the social and economic system of the region.

If the task of developing the region is a priority for implementation not only on paper, but also in the form of real measures, then there is a classic set of forms and methods of 
regional development. Moreover, if management has an understanding that a long-term strategy is necessary for the successful development of the region, then this fact alone is already a guarantee of success.

\section{RESULTS AND DISCUSSION}

The main question to be answered is the question of the possibility of applying this technique in practice. If we consider practical approaches in the field of implementing indicative planning, for example, those Russian regions that have already integrated this decision into the overall strategy of social and economic development strategy, such as Tatarstan, then the answer to this question is unequivocally affirmative, and moreover, it is confirmed by practical results.

Nevertheless, at the moment there is no region that would propose an integrated concept of indicative planning based on the principles of rational development of the social and economic system of the region. Tatarstan and the Krasnodar Territory are using the elements of indicative planning on their own, but they are far from using all the methods of indicative planning. Indicative planning is an evolutionary way of development of the social and economic system, but in the modern conditions there are a number of limiting factors that prevent the effective use of this method. We mean:

\section{Lack of legislative base.}

\section{Lack of highly qualified specialists.}

\section{Formal approach to the process of economic planning.}

4. The lack of interest of relevant structures (legislative, executive) in the creation of a unified methodology for the development and implementation of a model for indicative development of the region.

Despite these difficulties, the introduction of indicative planning at the moment is a necessity, rather than an invariant approach to managing the economy. The main reason is that a number of "classical" approaches, which manifested themselves in the reforms initiated in 1998-2000, proved to be unviable.

The same thing can be said about the proposed development strategy for 2000-2010, as well as further attempts to formulate and achieve certain goals in the development of the state economy. What are the main reasons for the failure of the reforms?

First of all, it is an orientation toward the raw material model of the economy, which led to:

1. Insufficient attention to the regions as drivers of the general economic recovery.

\section{Lack of perspective investment projects.}

3. There are no conceptions of development of regions as social and economic systems in the iterative format.

4. Insufficient attention to the revival of the processing industry.

The resolution of the above factors is mitigated by the indicative planning instruments, and, consequently, the result of long-term targeted measures, can be completely different, to say more precisely, when introducing a long-term strategy for the development of a state or a region, we can sooner achieve the goals and objectives.

The issues that exist in the regional development require their urgent resolution.

Each region is influenced by subjective factors that determine its development.

At the same time, there is a single goal that determines their effectiveness. This is the level of welfare of the population and the maintenance of a stable (financial, social) state of the region. At the moment, the difference in the definition of the standard of living of the population in the regions differs significantly; economic policy aimed at equalizing the standard of living of the population has not achieved a visible result. The incomes of the population in the regions vary considerably. The development of financial selfsufficiency of the regions according to the principle of indicative planning will allow increasing their economic activity in the established time interval, creating conditions for the economic growth of the region.

Of course, it will be necessary to take into account the geographical position of the region and the level of development of its social and economic system. There are two levels of implementation of the approach to introducing a long-term development strategy for the region in the concept of indicative planning:

1. Proposing a long-term development strategy for one region.

2. Proposing a long-term development strategy for a group of regions.

The principal difference is that if you develop an indicative plan for one region, it becomes possible to increase the potential of the region and balance the parameters of the social and economic system primarily due to the internal unrealized potential of the region. If the goal is to develop a group of regions, then an effective infrastructure project is needed to efficiently solve this problem, which will link this group of regions and will allow monitoring the pace of development of both the social and economic system of the "confederation" and directly its elements - social and economic systems of the region.

The use of indicative planning will involve various segments of the population in the development of the region and intensify the solution of social problems.

Taking into account the above-mentioned facts, we can consider the process of indicative planning as a crisisprevention instrument, which makes it possible to clearly assess the available resources and obtain first results in an expeditious manner, which is relevant for the current state of most regions of the Russian Federation. The need for prompt intervention is also linked to the fact that the standard of living in problem regions of the country is deteriorating from year to year, and, in addition, if we compare GRP (Gross Regional Product) of a single region and GDP (Gross Domestic Product) of one of the states of the world, we will get a picture 
in which some regions are in the position of the world's poorest countries.

Let us dwell on the perspective of applying indicative planning for a group of the regions, in this case, a certain global project will be implemented, influencing more than two regions. This kind of project will require the creation of a focal point that will work on the project, monitor the timing and reporting to the head of the federal body and the leadership of the regions that are part of this project. The implementation scheme can be constructed according to the model of the Appalachian Mountains development project or the Tennessee River Valley Corporation (depending on the project orientation). Unfortunately, at the moment there are only three projects in the Russian Federation that can be considered global in terms of attracting public funding: the construction of the Vostochny launch site, the Crimean bridge and, oddly enough, "Zenith" arena. If we consider spatial development projects, we can mention the Far East Corporation. Practically every region has its own development corporation, but in accordance with the concept of indicative economy they will not be able to fulfill the functions of developing the social and economic system of the region. The main product of the corporation's activities is introducing a strategy for the development of the region and the allocation of certain funds for "infrastructure projects." Such corporations are unable not only to manage the social and economic system of the region, but even to correct the economic course. The strategy developed by them is nothing more than a document. Without a mechanism for achieving goals, without a feedback mechanism, it is doomed to fail to execute medium-term tasks in a changing political and economic environment.

The variant with the use of the model of the formation of the corporation of the development of the region is good for the regions with the potential of industrial development and the corresponding features of the formation of capital. The coordination of interests of the state, industrialists and the population can be effectively realized through the prism of organization of the process of interaction in the format of a corporation, where they focus on social priorities, determining the priority directions for the development of the region, creating an appropriate favorable investment climate introducing subsidies and reduction of the tax burden. Thus, the economic potential of the territory will be developed by creating additional jobs.

In Tambov region two attempts were made to implement long-term strategic planning - Strategy 2020 and Strategy 2035.

Strategy 2020 was finally approved in 2013 and as soon as in 2017 a new long-term document is introduced until 2035, which indirectly confirms the fact that the goals and objectives set in Strategy 2020 have not been achieved. Since the interim results can be seen now, it is necessary to consider both positive and negative factors that either favor or impede the implementation of this document.

The most positive factor is the in-depth analysis carried out by economists, regarding the intersectoral development of the national economy and the general dynamics of the development of the social and economic system of Tambov region:

1. The drivers of the growth of the social and economic system of the region have been revealed.

2. The dynamics of the main social and economic indicators is analyzed.

3. SWAT-analysis was performed, allowing building a model for the development of the region's economy, relying on its strengths.

However, despite the high-performance work that deserves a positive assessment, initially Strategy 2020 could not be used as an effective tool for "regulation" of the social and economic system, for controlling the context of stabilization and improving the economic efficiency.

One of the main reasons is the lack of a clear financial model of Strategy 2020 due to the lack of an appropriate regulatory framework at the federal level. The draft law, prepared by S. Glazyev (Federal Law on Amendments and Additions to the Federal Law "On State Forecasting and programs for social and economic development of the Russian Federation", № 90023275-3), which provided effective legislative and methodological support for the development of long-term and medium-term strategies, both at regional and federal levels, using the achievements of economic science, was not adopted. Stead Federal Law of June 28, 2014 N 172FZ "On the strategic planning in the Russian Federation" (amended) was passed in 2014. These two documents are different in a whole set of positions, but the main integral difference is the lack of opportunity to form a coherent system of social and economic period with the possibility of rapid modification of existing activities in order to achieve strategic goals and objectives declared in the strategy (the Federal Law $-172)$.

First of all, we are talking about the system, rather than a set of different target programs generated at the federal and regional level, and an attempt to link them with each other, as it is done, for example, in the development Strategy 2020 in Tambov region. In practice of the Russian Federation, at the level of the Ministry of Finance and the Ministry of economic Development the main documents are the 3-year budget and social and economic outlook. In practice, those programs that are made for the long term, are rarely brought to an end, and they are either included into a state program from another agency or they are to be implemented within a longer period. Why should we take such actions and what will they bring? Firstly, it allows minimizing the differences between financial and physical indicators, which may result either from the crisis in the global economy, or from the corruption. Secondly, the changes in terms of validity of programs and program names do not affect the concept of the three-year budget because of the actual lack of integrity of the financial model.

Thus, the fulfillment of the tasks is impossible for objective reasons, and any correspondence of the results is nothing more than a coincidence, a guess, or a trend approximation. 
However, it is necessary to look positively at a number of existing factors, at least, the need for planning as a priority at the highest level.

Introduction of indicative planning in the economy will create conditions for stable growth.

\section{CONCLUSION}

Two levels of implementation of indicative planning are proposed:

- a long-term development strategy for one region;

- a long-term development strategy for a group of regions.

We made conclusions and marked the directions of development of this research area. Introduction of indicative planning in the economy will allow creating conditions for a stable growth of the well-being of the population. To promote this instrument, it is necessary to form a legislation that will allow using the indicative planning method [2].

\section{References}

[1] Mozgoev A.M., Paizullaev S.S. Indikativnoe planirovanie kak instrument razvitiya regona [Inducative planning as an instrument of regional development]. Sovremennye problemy upravleniya prirodnymi resursami i razvitiem sotsial'no-ekonomicheskikh sistem: Materialy XII mezhdunar.nauch.konf. $\mathrm{V} \quad 4 \mathrm{ch}$. [Contemporary problems of management by natural resources and development of social and economic systems: Proceeding of the XII international scientific conference. In 4 parts], 2016, pp.579-585.

[2] Smagina V.V., Strekalov N.V. Indikativnoe planirovanie kak perspektivnyj instrument upravlenija razvitiem social'nojekonomicheskih sistem na regional'nom urovne [Indicative planing as a perspective instrumetn of management by the development of social and economic systems at the regional level]. Vestnik Tambovskogo universiteta. Serija Gumanitarnye nauki [Bulletin of Tambov University. Series Humanities], 2014, № 11(139), pp. 139-142.

[3] Smagina V.V., Strekalov N.V. Indikativnaya ekonomika kak paradigma postkrizisnogo ekonomicheskogo razvitiya Rossiiskoi Federatsii [Indicative economy as a pardign of post crisis economic development of the Russian Federation]. Vektory smeny ekonomicheskogo rakursa [Vectors of the change of the economic angle], 2015, Chapter.36, pp. 309-314.

[4] Smagina V.V., Strekalov N.V. Metodologiya postroeniya i funktsionirovaniya struktur reguliruyushchikh protsess indikativnogo planirovaniya [Methodology of construction and functioning of the structures regulating the process of indicative planning]. Vestnik Tambovskogo universiteta. Seriya Gumanitarnye nauki [Bulletin of Tambov University. Series Humanities], 2015, №11 (151), pp 113-116. 